\title{
Concept and application of implant connection systems: Part II. Placement and restoration of external connection implant and tissue level implant
}

\author{
Kyung-Ho Ko, Hyeon-Goo Kang, Yoon-Hyuk Huh, Chan-Jin Park, Lee-Ra Cho* \\ Department of Prosthodontics and Research Institute of Oral Science, College of Dentistry, Gangneung-Wonju National University, \\ Gangneung, Republic of Korea
}

\begin{abstract}
To use the external connection implant (EXT) appropriately, the inter-implant distance should be carefully considered during placement, and the bones raised above the implants should be trimmed during the second surgery. The hex abutment is more useful than the non-hex abutment. EXT is particularly useful when the inter-arch space is limited. The tissue level (TL, internal butt connection) implant has a biomechanical advantage of coronal wall thickness and a biological advantage of an inherent transmucosal smooth surface. During TL implant restoration, an abutment can be selected using the abutment and fixture margins with considerations for the inter-arch space. Since no single type of implant can satisfy all the cases, it is necessary to select the appropriate type, considering the occlusal force and the bone condition. (J Dent Rehabil Appl Sci 2020;36(4):222-31)
\end{abstract}

Key words: external connection; tissue level; abutment; placement

\begin{abstract}
서론
임상적으로 널리 사용되는 대표적인 3가지 임플란 트와 지대주의 연결방식은 1) 안착형 외부 연결(slip fit external connection, EXT), 2) 원추형 내부 연결 (internal conical connection, ICC) 및 3) 안착형 내부 연 결(slip fit internal butt connection 또는 tissue level, TL) 임플란트이다. 한 가지 유형의 임플란트 만으로 모든 증 례에 적합한 결과를 내기 어려우므로 각 시스템의 장단 점과 적응증례를 잘 알고 선택하는 것이 필요하다. 세 가 지 유형 중 가장 오랫동안 사용되어 온 EXT는 최근에 사용빈도는 낮아졌으나 여전히 장점과 오랜 임상결과를 보유하고 있으므로 그 특성을 이해하고 꼭 필요한 경우 에 이용하는 것이 좋다. 또 TL은 EXT와 ICC의 장점을
\end{abstract}

*Correspondence to: Lee-Ra Cho

Professor, Department of Prosthodontics and Research Institute of Oral Science, College of Dentistry, Gangneung-Wonju National University, 7 Jukheon-gil, Gangneung-si, Gangwon-Do, 25457, Republic of Korea

Tel: +82-33-640-3153, Fax: +82-33-640-3103, E-mail: lila@gwnu.ac.kr

Received: September 16, 2020/Last Revision: October 12, 2020/Accepted:

October 13, 2020
함께 가지므로 맞는 상황에 선택하여 사용하는 것이 필 요하다. 지난 종설에서는 ICC의 생역학적 특성과 식립 및 보철의 주의사항을 다루었는데, 이번에는 EXT와 TL 의 특성에 맞는 식립 및 보철방법에 대해 다루고자 한다.

\section{외부 연결 임플란트의 식립과 보철방법}

$\mathrm{EXT}$ (안착형 외부연결) 임플란트는 가장 오랫동안 사 용되어 온 임플란트로 구조물 연결 시 적합 확인이 쉽고 원추형 내부연결(ICC) 임플란트에서 발생하는 수직변위 (axial displacement)가 적어 교합이 잘 유지되며 나사로 만 유지되기 때문에 탈착이 쉬운 특성을 가진다. 하지만 임플란트와 지대주의 직경이 대부분 동일하여 플랫폼 스 위칭(platform switching) 효과를 얻을 수 없고 수평골 소

Copyright@ 2020 The Korean Academy of Stomatognathic Function and Occlusion. (c) It is identical to Creative Commons Non-Commercial License. 
실이 발생하기 때문에 어떤 위치에 식립하더라도 일정 정 도의 골소실이 발생한다. ${ }^{1,2}$ 최근에는 EXT 형태가 예전과 달라져서 수평골 소실을 유발하는 상부의 폭은 줄었으나 수평골 유지에는 불리하고 연조직의 넓은 폭경에 의한 단단한 봉쇄가 ICC에 비해 불리하다(Fig. 1). 단점이라 지적되어 왔던 나사풀림은 임플란트 사용 초기에 토크를 가하는데 미숙했던 시기의 실패율이며 Part 1에서 설명했 듯이 실제로 ICC와 큰 차이가 없었다. ${ }^{3}$ 또한 임플란트 파 절빈도가 ICC에 비해 높지 않아 가급적 넓은 직경을 선 택해야 하는 ICC에 비해 선택의 부담이 크지 않다. ${ }^{4}$

$\mathrm{EXT}$ 는 구조상 안착부위가 좁아 기본적으로 나사에 응력이 집중되고 수평력에 대한 저항력이 낮은 편이다. ${ }^{5-7}$ ICC의 등장에 따라 EXT의 사용빈도는 크게 감소하였 는데 이는 ICC의 생역학적 장점이 부각되었기 때문이나, ICC가 태생적으로 가지는 한계를 감안하면 EXT의 한 계와 강점을 잘 알고 적용하는 것이 필요하다.

EXT는 ICC에 비해 수술이 약간 까다롭다. 임플란트 상부 벽두께를 확보하기 위해 ICC는 대부분 위로 갈수 록 넓어지는 형태를 택하고 있기 때문에 수술이 쉽지만 일자형인 EXT는 ICC에 비해 골삭제가 충분해야 식립
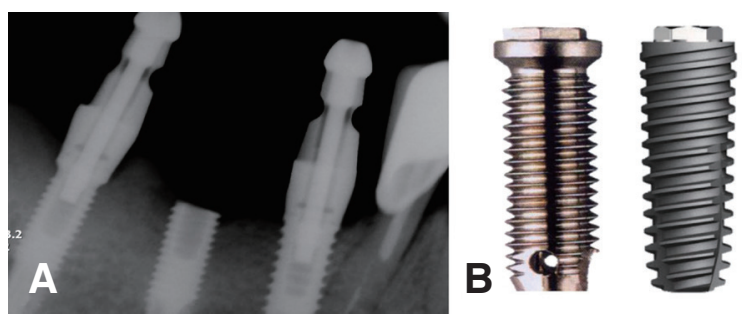

Fig. 1. (A) Comparison of external implant placed 25 years ago (\#47i) and newly placed implant (\#45i). The platforms are similar and can be connected with impression coping simultaneously. (B) Old external implant has wider horizontal platform, while this form cannot be observed in the newer one.
이 가능하다. EXT는 최근에 각광받고 있는 무피판 수술 (flapless surgery)에 적합한 형태는 아니며 임플란트를 깊 게 식립하고 지대주의 형태를 조절하는 최근의 수술경향 과는 다른 식립방법이 추천된다. EXT는 너무 깊게 식립 할 경우 지대주를 연결하기 어려우므로 피판을 거상하고 치조골정을 평평하게 다듬은 후 이보다 $1 \mathrm{~mm}$ 정도 하방 에 식립하는 것이 적절하다. 하지만 Monje 등 $^{8}$ 의 연구에 따라 향후 임플란트 주위염을 유발할 수 있는 인자 즉, 얇은 연조직형이나 비각화점막이 있는 경우라면 조금 더 깊게 식립해야 하는 것은 동일하다. 임플란트 간의 식립 간격이 $3 \mathrm{~mm}$ 보다 좁을 경우 골흡수를 유발한다는 것은 대부분 EXT에서 나타나는 현상이며, ${ }^{9,10} \mathrm{ICC}$ 보다는 식립 간격에 의한 골소실의 위험이 크기 때문에 특히 다수 임 플란트를 식립할 경우 임플란트 간 식립간격을 주의해야 한다(Fig. 2). ${ }^{11}$

$\mathrm{EXT}$ 의 치유지대주 연결 시 임플란트 상부로 자라 올 라온 주변골을 다듬어 주어야 한다. 치유지대주 연결 시 문제가 없더라도 인상코핑이나 지대주를 연결할 때 임플 란트 주변골이 방해될 수 있어 골 성형(bone profiling)이 필요할 수도 있다(Fig. 3).

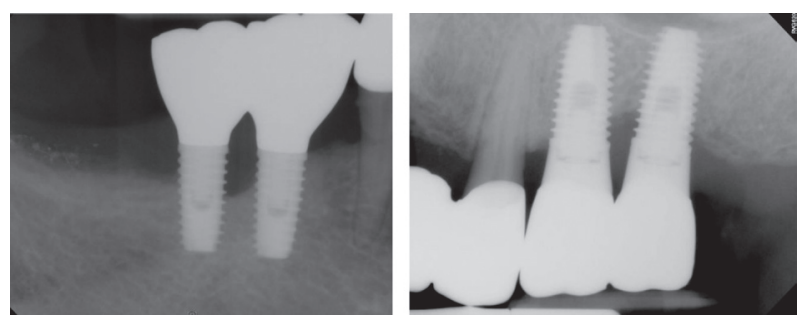

Fig. 2. Inter-implant bone loss induced by narrow interimplant distance. The inter-implant distance between EXT implants should be more than $3 \mathrm{~mm}$.
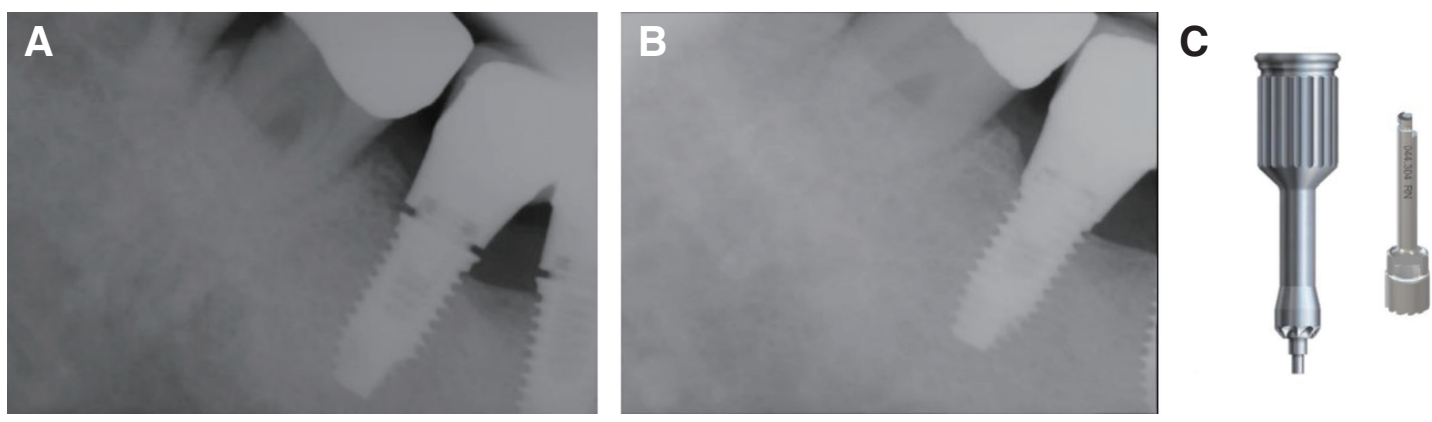

Fig. 3. (A) Prosthesis cannot be placed due to overgrowing distal bone. (B) After bone profiling with instruments, the prosthesis can be placed completely. (C) Bone profiler. 
EXT의 식립에 비해 보철은 쉽고 단순한 편이다. 인상 을 채득할 때 임플란트 수준에서 나사유지형으로 여러 임플란트를 연결하는 보철물만 아니라면 인상코핑의 종 류에 따른 차이도 크지 않다. ${ }^{12,13}$

ICC에서 원추형(conical, non-hex) 지대주는 임플란 트와의 접촉면적을 증가시키지만 EXT에서는 원추형 지 대주의 접촉면적이 더 작기 때문에 생역학적으로 불리하 다. Cardoso 등 ${ }^{14}$ 은 나사를 여러 번 조이고 풀림회전력을 측정하면 육각형 지대주의 풀림회전력이 원추형 지대주 에 비해 약간 높지만 큰 차이를 나타내지는 않는다고 하 였다. 따라서 나사의 문제라기 보다는 임플란트의 측방 력에 저항하는 면적 때문에 원추형 지대주보다는 가급적 육각형 지대주를 사용하는 것이 더 유용하다.

지대주의 위치를 확인하고 악간관계를 채득하기 위한 인덱스(positioning jig)도 ICC보다는 신뢰도가 높은 편 이다. 수직변위가 거의 발생하지 않으므로 연조직 형성 등 특별한 목적이 없다면 임시수복을 거치지 않고 바로 최종보철을 해도 되고, 인상만 정확하다면 보철물과 지
대주를 동시에 제작해도 된다. 다만 CAD-CAM 지대주 를 제작할 때 마무리가 부족하면 임플란트보다 넓게 제 작하는 경우가 있으며 특히 넓은 직경의 EXT를 위한 환 봉(titanium rod)의 질관리가 잘 되지 않아 환봉선택에 주 의해야 한다(Fig. 4). ${ }^{15,16}$

적합확인이나 장착에 큰 문제가 없으므로SCRP(screw and cement retained prosthesis)를 사용할 때 원추형 지 대주를 사용했다면 구외에서 합착해도 상관없다. 장기적 으로 보았을 때 탈착이 쉬워서 유지하기 편리하다는 것 이 가장 큰 장점이다.

$\mathrm{EXT}$ 식립이 특히 필요한 경우는 악간공간이 제한된 경우이다(Fig. 5). 이런 경우 ICC를 식립하면 지대주나 보 철물의 모양이 매우 불량해지며 TL은 악간공간 측면에 서 더 불리하여 시도하지 않는 것이 낫다. EXT는 ICC보 다는 넓은 플랫폼을 활용할 수 있어 특히 악간공간이 제 한된 구치부에서 활용도가 높다. 개구량이 제한되는 증 례에서도 임플란트 간 평행에 의한 영향을 덜 받는 EXT 가 유용하다.


Fig. 4. Misfit in the implant-abutment assembly. (A, B) CAD-CAM abutment misfit in regular diameter implant. (C) Internal space between implant-abutment assembly meant inappropriate titanium rod in wide diameter implant.
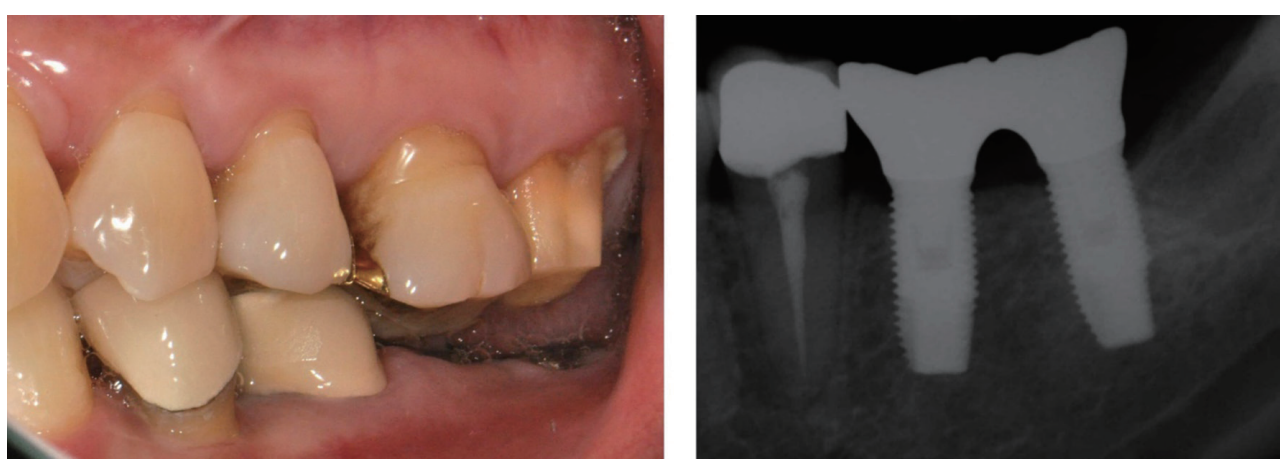

Fig. 5. Limited inter-occlusal distance. In this situation, external implant can be used rather than internal conical connection or tissue level implant. 


\section{안착형 내부연결 임플란트의 식립과 보철방법}

TL은 EXT와 함께 오랫동안 사용되어 왔으며 생물학 적 장점과 생역학적 장점을 동시에 가지고 있는 시스템 이다. TL은 점막을 통과하는 부위가 임플란트에 내재되 어 있기 때문에 필요에 따라 1 회법으로도, 2 회법으로도 수술할 수 있다. 점막관통부위가 임플란트에 있으므로 잠재적으로 골흡수를 유발할 수 있는 미세공극(microgap)이 골조직보다 상부에 위치한다. Hermann 등 $^{17,18}$ 의 연구에 따르면 외형을 동일하게 제작한 임플란트 중 $\mathrm{TL}$ 형태가 미세공극이나 잠재적 미세동요(micromovement) 가 있는 임플란트에 비해 골흡수를 작게 유발하였으며 치 조정 상방의 연조직부착(supracrestal tissue attachment) 두께도 $2.8 \mathrm{~mm}$ 로, 다른 임플란트에 비하여 작았다. 이는 연조직봉쇄를 더 얇은 연조직으로도 단단히 이룰 수 있음 을 의미하는 것이다. 실제로 다양한 임상연구에서 TL 임 플란트의 성공적인 결과가 보고되고 있다. ${ }^{19,20}$

$\mathrm{TL}$ 의 생물학적 장점이 주로 부각되어 왔으나 TL은 생 역학적으로 상당한 강점을 가지고 있다. TL은 모스경사 (morse taper)를 주장하며 원추형 봉쇄의 기본 개념을 최 초로 제시하였다. ${ }^{21}$ 내부 봉쇄와 함께 상부의 베벨부분을 이용하여 수평적으로 힘을 분산시킬 수도 있다. TL은 안 착형 내부연결 시스템이라서 EXT와 ICC의 장점을 함 께 가진다. EXT나 ICC와 비교할 때 TL은 수직적, 수평 적으로 유리한 모멘트를 가진다(Fig. 6). 또한 같은 내부 연결형인 ICC에서는 원추형 내부를 가지는 특수한 형태 로 인해 넓은 직경(wide neck)의 임플란트에서 경부 직경 이 작은 것에 비해 TL에서는 경부 직경이 더 크기 때문에

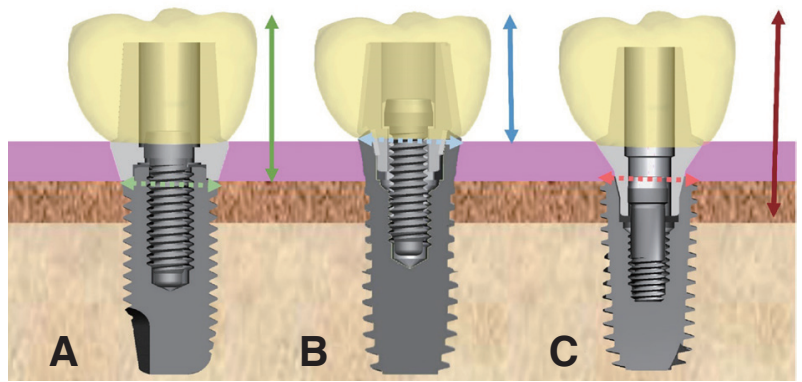

Fig. 6. Comparison of vertical and horizontal moment depending on implant types. (A) EXT, (B) TL, (C) ICC. $T L$ can provide most favorable vertical and horizontal moment.
(Fig. 7), 임플란트 본체의 강도도 매우 우수하여 임플란 트 파절이나 나사풀림 등 기계적 문제가 발생하는 빈도 가 낮아 생역학적으로 불리한 상황에도 안정적으로 사용 할 수 있다. ${ }^{22}$

길이와 직경만 선택하면 되는 EXT나 ICC와는 달리 TL은 임플란트 형태의 종류가 여럿이고 이용방법도 다 양하여 식립할 때 어려움을 느끼는 경우가 많다. TL 중 $\varnothing 4.0$ 은 골폭이 좁은 소구치에 적합하며 $\varnothing 4.5$ 는 소구치 나 골폭이 좁은 대구치 부위에 사용하고, Ø5.0은 골폭 이 넓은 대구치 부위에 사용한다. 또 임플란트의 직경이 달라도 일자형과 넓은 경부 형태는 상부 폭경이 다르므 로 골폭과 치아 폭경에 맞추어 임플란트를 선택한다(Fig. 8). 또 같은 직경과 상부 폭경을 가진 임플란트라도 연마 된 표면의 길이는 차이가 있어 치은관통부의 연조직 두께 에 따라 선택하기 때문에 선택의 기준만 알면 선택의 폭 이 넓은 것이 오히려 장점이 될 수 있다. 다만 연마된 표 면이 치조골 상부로 노출되는 것이 기본적인 형태여서 전 치부에 사용하면 치은색조에 문제가 있어 TL을 사용하 는 것이 큰 장점이 없다.

지대주를 착탈하면 주변골 상실이 발생한다는 Her$\operatorname{mann}$ 등 $^{17,18}$ 의 연구에 의하면 미세간극이 있는 임플란트 에서 반복적인 착탈은 최소화 하는 것이 필요하다. Alves 등 $^{23}$ 도 한 번 제거한 지대주 주위의 연조직이 완벽하게 치 유되려면 최소 6 개월이 필요하다고 하여 가급적 착탈을 최소화 할 것을 권유하였다. 이런 측면에서 연조직을 통 과하는 부위가 임플란트 고정체에 포함되어 착탈되지 않 는 TL은 연조직 건강 유지에 큰 도움이 된다.
A

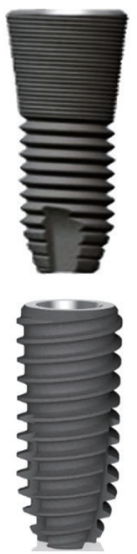

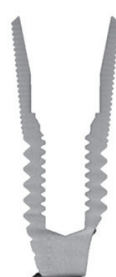

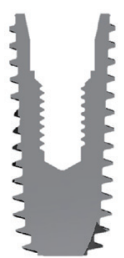

B

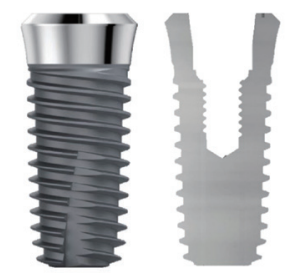

D

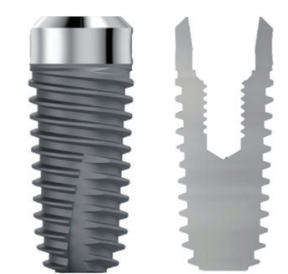

Fig. 7. Implant shape and section. Wide neck in ICC (A) has thinner coronal wall thickness compared to flat neck ICC (C), while wide neck in TL (B) has thicker coronal wall thickness compared to flat neck TL (D). 


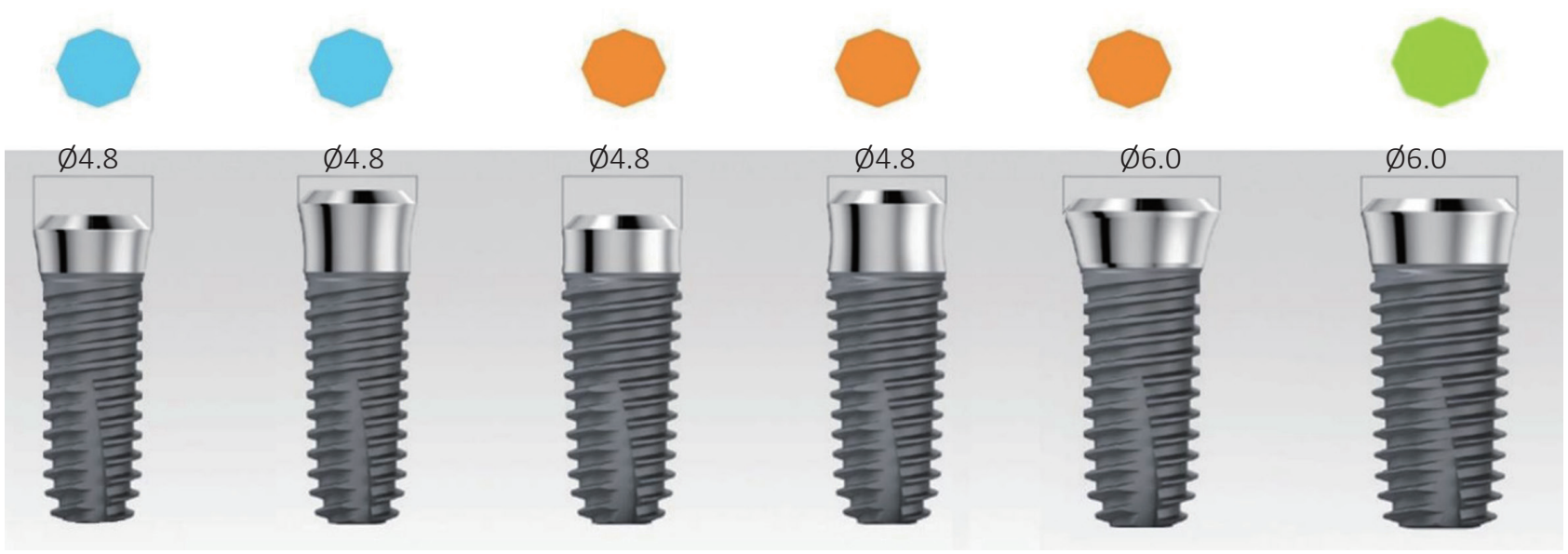

Fig. 8. Various shape and diameter in TL implants. $\varnothing 4.0$ (blue) implant for premolar implant placement with narrow horizontal bone condition. $\varnothing 4.5$ (orange) implant for premolar implant placement with wide horizontal bone condition or molar implant placement with narrow horizontal bone condition. $\varnothing 5.0$ (green) implant for molar implant placement with wide horizontal bone condition. Implant. Smooth surface height can be selected by considering the thickness of soft tissue. The number $(\varnothing)$ shown above the implants indicates the coronal width of an implant.

TL은 생역학적 강점이 큰 반면 점막관통부가 임플란 트에 내재되어 있어 식립 후 보철을 이용한 수정의 여지 가 적다. 따라서 식립 전에 충분히 계획을 수립하고 정확 하게 식립해야 한다. 특히 악간거리가 좁거나 협설 중 한 쪽으로 치우쳐 식립되는 경우 수정하기가 매우 어려우며, 보철형태가 매우 불량해 질 수 있다. 그러므로 지대주의 합착을 위해 필요한 최소한의 지대주 높이 $4 \mathrm{~mm}$ 와 상부 보철재료 두께 $2 \mathrm{~mm}$ 를 합한 $6 \mathrm{~mm}$ 이상의 악간거리를 가진 경우에 식립해야 한다. TL은 각도수정이 어렵기 때 문에 치아의 중심와와 일치하게 임플란트를 식립하는 것 이 좋으므로 가이드수술(guide surgery)을 이용하는 것이 제일 좋다. 식립할 때는 EXT와 마찬가지로 치조골정을 평평하게 다듬은 후 거친 표면과 부드러운 표면의 경계 부위가 $1 \mathrm{~mm}$ 정도 치조골 하방에 위치하게 식립하는 것 이 적절하다.

식립 시 고려할 사항이 많은 반면, 보철은 어떤 지대주 를 선택하는가에 따라 다양하게 활용할 수 있다. 만약 내 부 원추형 접촉만을 이용하는 지대주를 선택할 경우 ICC 와 같은 장점과 단점을 가진다. 이런 지대주는 나사유지 형 보철물을 위한 지대주여서 흔히 사용되지는 않으며 대부분은 상부의 베벨에서 지지를 얻는 지대주를 사용한 다. 하지만 상부 베벨에서의 안착을 이용하는 정도는 지 대주에 따라 다르다(Fig. 9). Fig. 9의 A 지대주 계열을 선 택하면 상부 베벨에서의 접촉에서 강한 지지를 얻고 원 추형 내면과는 단순한 접촉을 이루기 때문에 나사를 풀
면 바로 제거가 가능하여 EXT와 같은 성질을 가진다. 반 면, B 지대주 계열을 선택하면 주된 유지력을 원추형 내 면에서 얻으며 상부 베벨은 침하에 대한 일정 정도의 저 항을 제공한다. 하지만 두 지대주의 가장 큰 차이는 보철 물의 변연(margin) 위치이다. A 지대주는 보철물이 지대 주에 접촉하지만 $\mathrm{B}$ 지대주는 보철물이 임플란트 상부와 접촉한다. 따라서 $\mathrm{B}$ 지대주에 비해 $\mathrm{A}$ 지대주를 사용하 려면 충분한 악간공간이 확보되어야 하므로 임플란트가 좀 더 깊게 식립된 경우에 유용하다. 특히 상부의 연마부 위가 치은연하에 위치할 때 B 지대주를 사용하면 보철물 의 완전한 안착이 어렵고 합착제 제거가 매우 어렵기 때 문에 $\mathrm{A}$ 지대주를 사용하여 보철물과 접촉하는 변연위치 를 치은연상으로 위치시키게 할 수 있다. A 지대주는 다 수 임플란트를 식립한 경우에 더 적합한 유형으로 생역 학적 장점과 함께 유지관리의 편의성 측면에서 특히 유리 하다. B 지대주는 단일 임플란트가 치은연상 변연을 가 질 때 가장 적절하며 제거의 편의성은 ICC보다는 우수하 지만 증례에 따라 불리한 경우도 있어 예측가능성이 낮 은 편이다. TL의 지대주 선택에 따라 EXT처럼 사용할 수도, ICC처럼 사용할 수도 있다는 구조적 범용성은 장 점이기도 하지만 선택의 어려움을 유발하는 요인이 되기 도 하므로 사용 전에 증례를 파악하여 확실한 기준을 수 립한 후 지대주를 선택하는 것이 필요하다.

CAD-CAM 지대주는 대부분 밀링된 연결부를 가진 환 봉을 가공하여 제작하는데, TL 시스템의 구조적 복잡성 
A

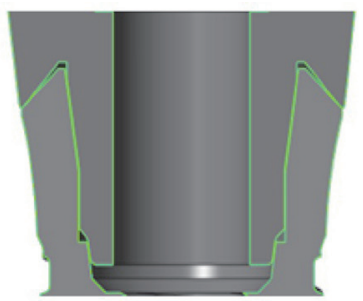

B

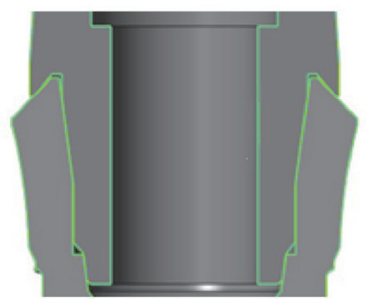

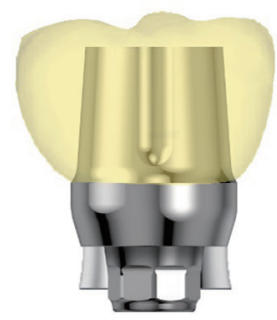



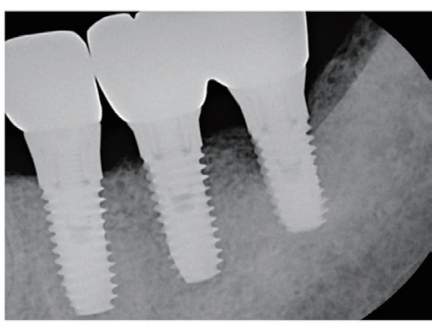

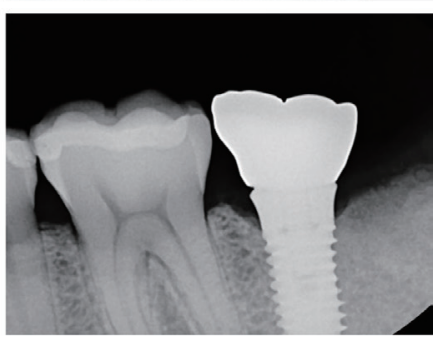

Fig. 9. The types of abutment and connection. (A) Abutment margin system for sufficient inter-arch distance. Simple retrievability can be possible due to using upper bevel in TL. (B) Fixture margin system for limited inter-arch distance. Favorable crown shape can be possible. However, the removal of excess cement and perfect seating would be difficult in some cases.
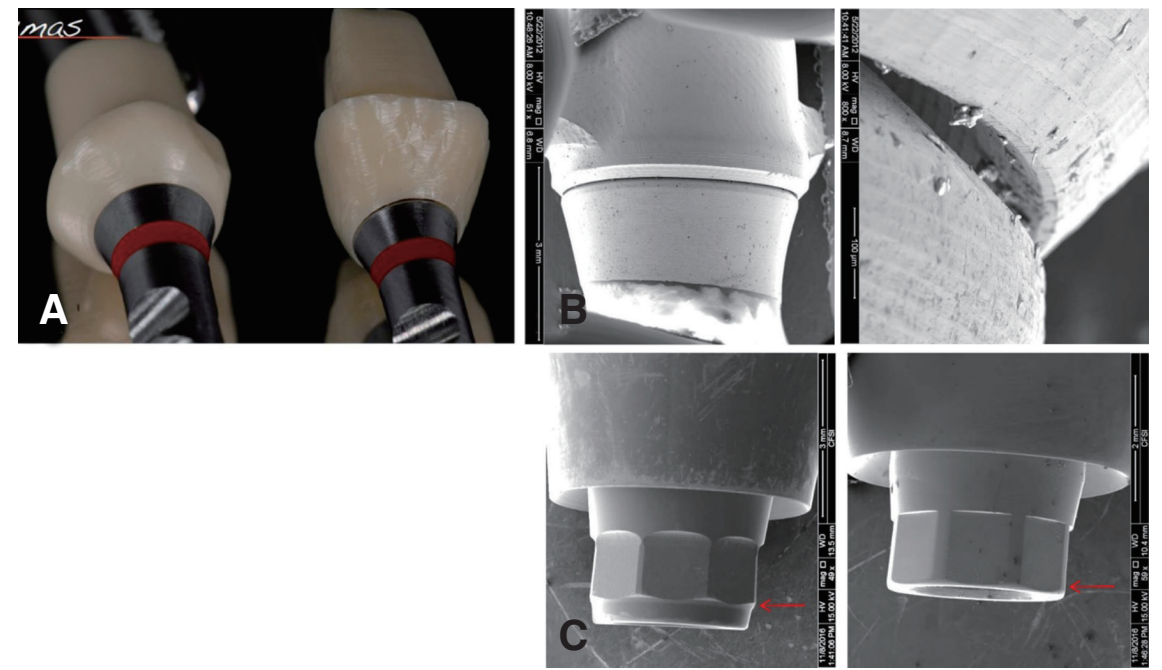

Fig. 10. (A) 2 CAD-CAM abutments of TL implant made by different laboratory. (B) Scanning electron micrographic image of $A$ abutment. Observation of the abutment below reveals the misfit of abutment. (C) Comparison of CAD-CAM abutments of TL made with different titanium blocks. The connection in the abutment is completely different.

으로 인해 호환성 환봉의 질적 수준이 다른 시스템에 비 해 더 불량하다(Fig. 10). 거시적으로 관찰할 때도 연결부 가 불량한 경우도 있으며 거시적으로 볼 때 적절해 보이 는 경우도 아래에서 관찰하면 적합도가 불량한 경우도 많다. 따라서 가급적 기성 지대주나 정품 환봉을 사용하 는 것이 추천된다

\section{부위별 임플란트 선택}

단일 임플란트로 모든 증례를 해결하려는 경우가 많지 만 모든 임플란트가 장단점이 있기 때문에 두 가지 시스 템 이상을 구비하고 적응증에 맞는 임플란트 시스템을 선택하는 것이 장기적인 문제를 방지할 수 있다. Part 1, 2에서 정리하였던 EXT, ICC 및 TL 임플란트의 생물학 
적, 생역학적 특성을 요약하면 Table 1과 같다.

구강 내에서 고려해야 할 사항은 부위별로 다르다. 전 치는 교합평면에 대하여 경사져 있기 때문에 가해지는 수직력이 작고 교합력의 크기도 작은 편이나 수평력은 크게 가해진다. ${ }^{24,25} \mathrm{Yi}$ 등 ${ }^{4}$ 에 따르면 구성요소 파절은 부 위와 임플란트 연결 시스템에 따라 다른데 주로 상악 구 치와 하악 구치에서 ICC의 파절이 나타나는 반면, 상악 전치에서는 수평력에 취약한 EXT의 파절이 나타난다고 하였다. 특히 회복불가능한 임플란트 본체 파절은 구치 부에서만 발생하고 상악 전치에서는 EXT의 나사 파절 이 전부였음을 감안하면 구치부에 ICC를 식립하는 것은 골질이 나쁜 상악에 한정하는 것이 좋으며 ICC끼리 대 합되지 않도록 주의를 기울여야 한다. 또한 ICC에서 피 할 수 없는 수직변위로 인한 교합 변화와 생역학적 부작 용을 고려하면 유지관리에 어려움이 있는 ICC를 사용하 는 것보다는 EXT나 TL을 사용하는 것이 더 추천된다. TL을 이용할 때 단일 임플란트는 임플란트 베벨을 보철
물 변연으로 이용하는 지대주를, 다수 임플란트는 지대 주 변연을 보철물 변연으로 이용하는 지대주를 이용한 다. 특히 단일 임플란트는 ICC의 장점을 활용할 수 있는 원추형 지대주를 사용할 수 없어 다른 시스템을 더 적극 적으로 고려하는 것이 필요할 것이다. 이상과 같은 요인 을 요약하여 그림으로 표현한 것이 Fig. 11이다.

\section{결론}

대중적으로 널리 사용되고 있는 ICC는 장점과 단점이 명확하기 때문에 이를 이용하여 모든 증례를 해결하려 하기보다는 다른 시스템을 이해하고 임상의 범위를 넓히 는 것이 필요하다. ICC 는 원추형 내부연결 시스템으로 측방력에 안정적이고 생물학적 반응이 우수하며, EXT 는 전통적인 외부연결형으로 임플란트 상부에서 침하를 방지하는 안착형이며 보철의 편의성과 유지관리에 장점 이 있다. TL은 특히 생역학적으로 장점을 가지며 선택의

Table 1. Characteristics of implant systems

\begin{tabular}{lccc}
\hline & EXT & TL & ICC \\
\hline Bone/soft tissue health & Medium & Favorable & Favorable \\
Stability of connection \& screw (Axial displacement) & Medium & Favorable & Unfavorable \\
Fracture resistance & Medium & Favorable & Unfavorable \\
Surgical difficulty & Medium & Difficult & Easy \\
Prosthetic difficulty & Easy & Medium & Difficult \\
Maintenance difficulty & Easy & Easy & Difficult \\
\hline
\end{tabular}

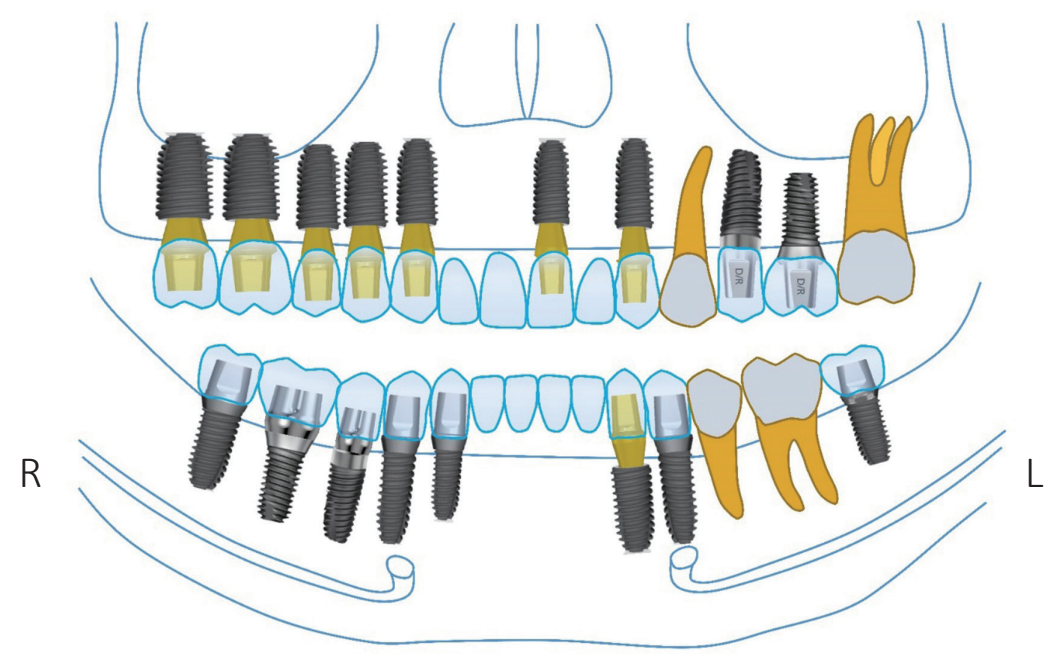

Fig. 11. Selection of implant system considering occlusal load and biomechanical characteristics of implant. Left side meant single implant restoration, while right side meant multiple implant restoration. 
폭이 다양하고 두 시스템의 장점을 모두 활용할 수 있는 지대주를 사용할 수 있는 시스템이다. 한 가지 임플란트 만 선택하여 맞이하는 장기적 임상부작용을 극복하려면 적절한 임플란트를 적절한 곳에 선택하는 지혜가 필요하 리라 사료된다.

\section{ORCID}

Kyung-Ho Ko https://orcid.org/0000-0002-1260-8844

Hyeon-Goo Kang https://orcid.org/0000-0001-6293-0121

Yoon-Hyuk Huh https://orcid.org/0000-0003-4072-5199

Chan-Jin Park https://orcid.org/0000-0003-4734-214X

Lee-Ra Cho https://orcid.org/0000-0003-3989-2870

\section{References}

1. Weng D, Nagata MJ, Bell M, Bosco AF, de Melo LG, Richter EJ. Influence of microgap location and configuration on the periimplant bone morphology in submerged implants. An experimental study in dogs. Clin Oral Implants Res 2008;19:1141-7.

2. Weng D, Nagata MJ, Bell M, de Melo LG, Bosco AF. Influence of microgap location and configuration on peri-implant bone morphology in nonsubmerged implants: an experimental study in dogs. Int J Oral axillofac Implants 2010;25:540-7.

3. Theoharidou A, Petridis HP, Tzannas K, Garefis P. Abutment screw loosening in single-implant restorations: a systematic review. Int J Oral Maxillofac Implants 2008;23:681-90.

4. Yi Y, Koak JY, Kim SK, Lee SJ, Heo SJ. Comparison of implant component fractures in external and internal type: A 12-year retrospective study. J Adv Prosthodont 2018;10:155-62.

5. Pessoa RS, Muraru L, Júnior EM, Vaz LG, Sloten JV, Duyck J, Jaecques SVN. Influence of implant connection type on the biomechanical environment of immediately placed implants - CT-based nonlinear, three-dimensional finite element analysis. Clin Implant Dent Relat Res 2010;12:219-34.

6. Asvanund P, Morgano SM. Photoelastic stress analysis of external versus internal implant-abutment connections. J Prosthet Dent 2011;106:266-71.

7. de Almeida Prado Naves Carneiro T, Dietrich L,
Prudente MS, da Silva Neto JP, do Prado CJ, de Araújo CA, das Neves FD. Fracture Resistance of Internal Conical and External Hexagon: Regular and Narrow Implant-Abutment Assemblies. Implant Dent 2016;25:510-4.

8. Monje A, Galindo-Moreno P, Tözüm TF, SuárezLópez del Amo F, Wang HL. Into the Paradigm of Local Factors as Contributors for Peri-implant Disease: Short Communication. Int J Oral Maxillofac Implants 2016;31:288-92.

9. Tarnow DP, Cho SC, Wallace SS. The effect of inter-implant distance on the height of inter-implant bone crest. J Periodontol 2000;71:546-9.

10. Cardaropoli G, Wennström JL, Lekholm U. Periimplant bone alterations in relation to inter-unit distances. A 3-year retrospective study. Clin Oral Implants Res 2003;14:430-6.

11. Jo DW, Yi YJ, Kwon MJ, Kim YK. Correlation between interimplant distance and crestal bone loss in internal connection implants with platform switching. Int J Oral Maxillofac Implants 2014;29:296302.

12. Lee H, So JS, Hochstedler JL, Ercoli C. The accuracy of implant impressions: a systematic review. J Prosthet Dent 2008;100:285-91.

13. Gracis S, Michalakis K, Vigolo P, von Steyern PV, Zwahlen M, Sailer I. Internal vs. external connections for abutments/reconstructions: a systematic review. Clin Oral Implants Res 2012;23 Suppl 6:202-16.

14. Cardoso M, Torres MF, Lourenço EJ, de Moraes Telles D, Rodrigues RCS, Ribeiro RF. Torque removal evaluation of prosthetic screws after tightening and loosening cycles: an in vitro study. Clin Oral Implants Res 2012;23:475-80.

15. Ko KH, Park JH, Cho LR. Considerations for fabrication of cad-cam abutments: Part I. Selection of titanium block and fabrication process. Implantology 2019;23:46-58.

16. Ko KH, Park JH, Cho LR. Considerations for fabrication of cad-cam abutments: Part II. Designing abutment. Implantology 2019;23:112-25.

17. Hermann JS, Buser D, Schenk RK, Cochran DL. Crestal bone changes around titanium implants. A histometric evaluation of unloaded non-submerged 
and submerged implants in the canine mandible. J Periodontol 2000;71:1412-24.

18. Hermann JS, Buser D, Schenk RK, Schoolfield JD, Cochran DL. Biologic Width around one- and twopiece titanium implants. Clin Oral Implants Res 2001;12:559-71.

19. Behneke A, Behneke N, d'Hoedt B. A 5-year longitudinal study of the clinical effectiveness of ITI solid-screw implants in the treatment of mandibular edentulism. Int J Oral Maxillofac Implants 2002;17:799-810.

20. Buser D, von Arx T. Surgical procedures in partially edentulous patients with ITI implants. Clin Oral Implants Res 2000;11 Suppl 1:83-100.

21. Buser D, Mericske-Stern R, Dula K, Kang NP. Clinical experience with one-stage, non-submerged dental implants. Adv Dent Res 1999;13:153-61.

22. Morton D, Gallucci G, Lin WS, Pjetursson B, Polido W, Roehling S, Sailer I, Aghaloo T, Albera H, Bohner L, Braut V, Buser D, Chen S, Dawson A, Eckert S, Gahlert M, Hamilton A, Jaffin R, Jarry C, Karayazgan B, Laine J, Martin W, Rahman L, Schlegel A, Shiota M, Stilwell C, Vorster C, Zembic A, Zhou W. Group 2 ITI Consensus Report: Prosthodontics and implant dentistry. Clin Oral Implants Res 2018;29 Suppl 16:215-23.

23. Alves CC, Muñoz F, Cantalapiedra A, Ramos I, Neves M, Blanco J. Marginal bone and soft tissue behavior following platform switching abutment connection/disconnection-a dog model study. Clin Oral Implants Res 2015;26:983-91.

24. Fontijn-Tekamp FA, Slagter AP, Van Der Bilt A, Van't Hof MA, Witter DJ, Kalk W, Jansen JA. Biting and Chewing in Overdentures, Full Dentures, and Natural Dentitions. J Dent Res 2000;79:151924.

25. Morneburg TR, Pröschel PA. Measurement of masticatory forces and implant loads: a methodologic clinical study. Int J Prosthodont 2002;15:20-7. 


\section{임플란트 연결부의 개념과 적용: Part 2. 안착형 외부 및 내부 연결형 임플란트의 식립과 보철}

고경호 조교수, 강현구 전임의, 허윤혁 부교수, 박찬진 교수, 조리라* 교수

강릉원주대학교 치과대학 보철학교실 및 구강과학연구소

안착형 외부 연결 임플란트를 적절히 사용하기 위해서는 식립 시에 임플란트 간의 간격에 주의해야 하며 2차 수술 시에 임플란트 상부로 올라간 골을 다듬어야 한다. 육각형태를 가진 지대주가 원형 지대주에 비해 유용하다. 외부 연결형 임 플란트는 악간간격이 제한된 경우에 적용할 수 있다. 안착형 외부연결(조직수준) 임플란트는 상부 직경의 두께로 인한 생역학적 장점과 내재된 점막관통부로 인한 생물학적 장점을 가지고 있다. 조직수준 임플란트를 수복할 때 지대주 수준 과 임플란트 수준의 변연 중 악간공간에 따라 선택한다. 어떤 한 가지 임플란트 종류로는 모든 증례를 만족시키기 어려 우므로 교합력 및 골조건을 고려하여 적절한 임플란트를 선택하는 것이 필요하다.

(구강회복응용과학지 2020;36 (4):222-31)

주요어: 외부연결형; 조직수준; 지대주; 식립

*교신저자: 조리라

(25457)강원도 강릉시 죽헌길 7, 강릉원주대학교 치과대학 치과보철학교실 및 구강과학연구소

Tel: 033-640-3153 | Fax: 033-640-3103 | E-mail: lila@gwnu.ac. kr

접수일: 2020년 9월 16일 | 수정일: 2020년 10월 12일 | 채택일: 2020년 10월 13일 